\title{
MODERNIZACJA GÓRNICTWA ROSYJSKIEGO ZA PANOWANIA PIOTRA I. WPROWADZENIE DO PROBLEMATYKI
}

\section{Paweł KROKOSZ}

Uniwersytet Papieski Jana Pawła II w Krakowie, pawel.krokosz@upjp2.edu.pl

Kolegium Górnictwa i Manufaktur, górnictwo rosyjskie w XVI-XVIII $w$., car Piotr I, „przywilej górniczy” $1719 r$.

\footnotetext{
Artykuł poświęcony jest modernizacji górnictwa rosyjskiego, jaka miała miejsce za panowania cara Piotra I i stanowi wprowadzenie do szerszego omówienia spraw związanych z rozwojem i funkcjonowaniem tej gałęzi gospodarki w Imperium Rosyjskim. Uporządkowanie kwestii dotyczących pozyskiwania surowców naturalnych, przede wszystkim rud metali, było rzeczą konieczną, gdyż w znacznym stopniu zmniejszało ich eksport i pozwalało na prowadzenie rodzimej, o wiele tańszej, produkcji. Było to o tyle istotne, że Rosja w latach 1700-1721 toczyła wojnę ze Szwecją, a potrzeby carskiej armii były ogromne. W 1718 r. został utworzony nowy organ administracji państwowej, pod oficjalna nazwą - Kolegium Górnictwa i Manufaktur, który objął nadzór nad wszystkimi sprawami górniczymi państwa. W roku następnym Piotr I wydał akt prawny, tzw. przywilej górniczy, określający prawa związane $\mathrm{z}$ prowadzeniem wydobywania $\mathrm{i}$ przetwarzania rud metali oraz minerałów. Znaczący udział w rozwoju górnictwa rosyjskiego mieli specjaliści przybywający z Europy Zachodniej, przede wszystkim z krajów niemieckich.

W artykule wykorzystano rosyjskojęzyczne źródła oraz opracowania historyczne dotyczące funkcjonowania górnictwa rosyjskiego w XVI-XVIII w. Rezultatem analizy wspomnianych materiałów jest przekaz zawierający informacje związane $\mathrm{z}$ procesem ustanowienia urzędu państwowego odpowiedzialnego za sprawy związane z poszukiwaniem, wydobyciem i przetwórstwem wszelkich bogactw naturalnych.
} 


\section{Wstęp}

Na przełomie XVII i XVIII w. ${ }^{1}$ Rosja, za sprawą cara Piotra I (1682-1725) weszła na drogę gruntownych przemian, które całkowicie zmieniły jej dotychczasowe oblicze. Zainicjowane przez władcę reformy objęły niemal wszystkie kwestie związane z funkcjonowaniem państwa - administrację, wojsko, zwyczaje i obyczaje, sprawy religijne (działalność Cerkwi prawosławnej) oraz gospodarkę. Działania podjęte w zakresie ostatniego z wymienionych aspektów były znamienne, gdyż w znacznej mierze decydowały o powodzeniu pozostałych carskich inicjatyw. Stworzenie sieci dobrze funkcjonujących przedsiębiorstw produkujących na potrzeby cywilne, a w ówczesnej sytuacji przede wszystkim na rzecz armii zaangażowanej w walkę ze Szwecją na frontach III wojny północnej (1700-1721), było koniecznością. Tym sposobem większość powstających w owym czasie w Rosji manufaktur nastawiona były głównie na produkcję przeznaczoną na ogromne potrzeby wojska, a także budowanej od podstaw floty wojennej. W takich okolicznościach uregulowanie spraw związanych z niezakłóconą niczym pracą rodzimych zakładów produkujących uzbrojenie i wszelaki sprzęt wojskowy było zadaniem pierwszoplanowym. To z kolei pociągało za sobą potrzebę uporządkowania wszystkiego co było związane z poszukiwaniem i eksploatacją znajdujących się na terytorium Rosji rud metali. Tym sposobem rozwój rosyjskich przedsiębiorstw metalurgicznych był ściśle związany z rozwojem górnictwa, co w konsekwencji przełożyło się na administracyjne połączenie obydwu sprzężonych ze sobą gałęzi gospodarki. Decyzją podjętą przez Piotra I w 1717 r. powołano do życia nowy centralny urząd państwowy - odpowiednik współczesnego ministerstwa - Kolegium Górnictwa i Manufaktur (ros. Берг- и Мануфактур-коллегия), przy czym niemal od samego początku w oficjalnej dokumentacji używano tylko pierwszego członu całej nazwy (PSZRI, 1830, 5; Baburin, 1939; Anisimov, 1997; Kiselev, $2015)^{2}$. Dla górnictwa rosyjskiego otwierał się nowy, a zarazem zasadniczy etap, który wytyczył kierunek jego dalszego rozwoju.

Jak zauważył Władysław Romanow informacje, na podstawie których można mówić o początkach górnictwa rosyjskiego, a w zasadzie górnictwa rozwijającego się na ówczesnych ziemiach Wielkiego Księstwa Moskiewskiego, można odnaleźć już w źródłach z 2. poł. XV w. Same dzieje górnictwa ruskiego (później rosyjskiego), bez wątpienia, zapoczątkował rozwijający się w wielu

\footnotetext{
${ }^{1} \mathrm{~W}$ artykule stosowana jest datacja wg kalendarza juliańskiego obowiązującego w Rosji od 1 stycznia 1700 r. do 1918 r.

${ }^{2}$ Władysław Serczyk podaje nieco inną nazwę tej instytucji: Kolegium Kopalni i Manufaktur (Serczyk, 1973).
} 
niezależnych ośrodkach, choć mających ze sobą pewne związki, przemysł solowarski (Romanov, 2015). Eksploatacja słonej wody pochodzącej z mórz i jezior, a przede wszystkim zalegających pod ziemią źródeł solankowych, aż do początku XX w. stanowiła podstawę rosyjskiego górnictwa solnego (dopiero w poł. XVIII w. zaczęto na niewielką skalę wydobywać sól kamienną w rejonie Iliecka). Początkowo produkcją soli warzonej zajmowały się przedsiębiorstwa należące do poszczególnych klasztorów rosyjskich oraz większych, bądź mniejszych prywatnych przemysłowców solowarskich. Zakłady produkcyjne, na mniejszą skalę, organizowały również władze państwowe. Wielki wkład w rozwój rosyjskiego warzelnictwa wnieśli poszczególni przedstawiciele rodziny Stroganowów, przy czym żyjący w 2. poł. XVII i na początku XVIII w. Grigorij Stroganow zdołał stworzyć swoistą ,potęgę solowarską”, dostarczając w XVIII stuleciu każdego roku ok. 3000000 pudów soli, co stanowiło $60 \%$ ogólnej produkcji krajowej tego surowca ${ }^{3}$ (Krokosz, 2012; 2014).

\section{Początki górnictwa rud metali i metalurgii w Rosji}

Warzelnictwo stanowiło istotny element składowy rosyjskiego górnictwa, lecz z biegiem lat o jego prawdziwym charakterze decydowało pozyskiwanie rud metali oraz minerałów. Pod koniec XV w. wielki książę moskiewski Iwan III (1462-1505) polecił swemu posłowi Julianowi Trachaniotowi (Grekowi z pochodzenia) wysłanemu do cesarza niemieckiego rozpoznać czy tamtejsi specjaliści z zakresu górnictwa nie zechcieliby wstąpić na jego służbę. Owocem tej misji było przybycie do Moskwy dwóch Niemców - Iwana (Johanna) i Wiktora, którzy wspólnie z miejscowymi „mistrzami od spraw górniczych” przystąpili do poszukiwań rudy srebra nad brzegami rzeki Peczory. Podjęte działania zakończyły się sukcesem, gdyż w 1491 r. nad brzegami wpadającej do Peczory rzeki Cylmy grupa poszukiwawcza odkryła rudę srebra, a także rudę miedzi. Jednakże do zakrojonego na szerszą skalę pozyskiwania rud metali doszło w połowie XVI w. za panowania cara Iwana IV Groźnego (1547-1584). Pod koniec lat 60. XVI w. monarcha zezwolił kupcom i przemysłowcom angielskim osiąść nad rzeką Wyczegdą, obdarzając ich prawem poszukiwania i wytapiania odkrytych przez siebie $\mathrm{w}$ tym regionie rud metali. Cudzoziemcy mieli również nauczać sztuki metalurgii carskich poddanych; pozwolono im również wywozić

\footnotetext{
${ }^{3} 1$ pud $=16,38 \mathrm{~kg}$, z przeliczenia wynika, że Grigorij Stroganow dostarczał na rynek rosyjski każdego roku około $49140000 \mathrm{~kg}$ (49 140 ton) soli.
} 
gotowe produkty po uiszczeniu stosownej opłaty w wysokości 1 dieńgi $^{4} \mathrm{za}_{\text {funt. }}$ Iwan IV Groźny czynił również starania o ściągniecie na swoją służbę metalurgów ze Szwecji, wyrażając jednocześnie zgodę na swobodny przywóz z tego kraju tak brakujących w Rosji: miedzi, cyny, ołowiu oraz siarki. Nadzór nad organizacją wydobycia i handlu prowadzonych przez Anglików car powierzył solwyczegodzkim solowarom - Jakowowi Strognowowi i Leontijowi Pyrskiemu. Jak zauważył Aleksander Wwiedeński także członkowie rodziny Stroganowów, mający możliwość bliższego przyjrzenia się sprawom dotyczącym eksploatacji i przetwórstwa rud metali, sami byli tym zainteresowani, gdyż wszystkie narzędzia (świdry, łomy, łopaty) i części żelazne (panwie, haki), tak niezbędne do prowadzenia produkcji soli były drogie i trudne do zdobycia. Oprócz tego Stroganowowie posiadali wiedzę gdzie w okolicach Soli Wyczegodzkiej (późniejszego Solwyczegodzka) występują złoża rud metali. Chęć zajęcia się przez nich produkcją żelaza docenił Iwan IV Groźny, wydając 18 maja 1577 r. na imię Jakowa Stroganowa stosowną gramotę, w której zezwolił mu zbudować zakład odlewniczy i rozpocząć produkcję żelaza w okolicach Soli Wyczegodzkiej (Vviedenskij, 1962; Romanov, 2015).

Za panowania tego władcy miała miejsce również intensywna akcja kolonizacyjna rozległych terenów rozciągających się przed i za górami Ural, w której pierwszoplanowa rola przypadła wspomnianej rodzinie Stroganowów. 4 kwietnia 1588 r. car Fiodor Iwanowicz (syn Iwana IV Groźnego) wydał Grigorijowi Stroganowowi „żałowanną gramotę" (przywilej), na mocy której oddawał w jego władanie ziemie leżące nad rzeką Kamą, zwalniając go jednocześnie na lat $20 \mathrm{z}$ daniny i podatków. Przedsiębiorca na powierzonych sobie ziemiach miał karczować lasy i zakładać pola uprane, trudnić się handlem i rybołówstwem. Otrzymał również zgodę na budowę umocnionego ostrogu (fortu) wyposażonego w armaty, dającego ochronę kolonizatorom przed napadami miejscowej ludności. Nad bezpieczeństwem miał czuwać wystawiony przez niego oddział zbrojny posiadający broń palną. Jednakże tym co najbardziej interesowało solwyczegodzkiego solowara, i co także kilkukrotnie zostało ujęte w carskim przywileju, było poszukiwanie, a następnie eksploatacja owych podziemnych źródeł solankowych: „(...) w tym miejscu należy solanek szukać, a gdzie zostana znalezione, to tam sól ma on warzyć”. Oprócz tego, o czym także mówił ów dokument, Stroganow miał również zajmować się poszukiwaniem rud srebra i ołowiu: „A gdzie zostanie odnaleziona ruda srebra, lub miedzi albo cynku, to natychmiast Grigorij ma o tych rudach zawiadamiać naszych urzędników skarbowych, $i$ samodzielnie tych rud nie wydobywać bez naszego zezwolenia" (Miller, 1937). Zdaniem Rogera Portala Grigorij Stroganow i pozostali

\footnotetext{
${ }^{4}$ rubel moskiewski $=2$ połtinom $=10$ grzywnom $=33$ ałtynom i 2 dieńgom $=200$ dieńgom; 1 grzywna $=3$ ałtynom i 2 dieńgom $=20$ dieńgom; 1 ałtyn $=6$ dieńgom.
} 
członkowie jego rodziny nie byli w żaden sposób zainteresowani eksploatacją tych ostatnich surowców naturalnych (Portal, 1950). Takie twierdzenie wykluczają jednak fakty potwierdzające prowadzenie przez Stroganowów w XVII w. na terenach swych permskich wotczyn (dóbr alodialnych) wydobycia i przetwarzania rud żelaza oraz miedzi (Vviedenskij, 1962).

Szybkie tempo kolonizacji ogromnych obszarów Syberii w ciągu całego XVII stulecia skutkowało odkrywaniem tam kolejnych bogactw naturalnych i powstawaniem nowych - bardzo często działających jedynie czasowo - zakładów produkcyjnych. Podobnie jak miało to miejsce uprzednio poszukiwaniem rud metali i źródeł solankowych oraz zakładaniem przedsiębiorstw gdzie były one przetwarzane, zajmowały się zarówno władze skarbowe, jak i prywatni przedsiębiorcy, a także poszczególne klasztory cieszące się carskimi przywilejami na prowadzenie działalności gospodarczej (DAI, 1853, 5; DAI, 1857, 6; Lubomirov, 1937).

Przykładem aktywności ze strony państwa na tym polu jest założony w $1635 \mathrm{r}$. u ujścia rzeki Pyskorki do Kamy, w pobliżu Usolia i Soli Kamskiej (późniejszego Solikamska) zakład zajmujący się przeróbką rudy miedzi. W jego uruchomieniu musiano jednak oprzeć się na doświadczeniu specjalistów przybyłych z Saksonii pod kierownictwem ,mistrza odlewniczego" Arista Petzolda (Petzolta), wspieranego przez 15 innych saskich specjalistów. Surowiec, dostarczany drogą wodną do zbudowanej specjalnie na potrzeby przedsiębiorstwa przystani, pochodził $\mathrm{z}$ uruchomionej w tym rejonie kopalni. W latach 1641-1643 zakład został przeniesiony na nowe miejsce i częściowo zmodernizowany. Pożar z 1648 r., a następnie wyczerpanie się pobliskich złóż rudy miedzi (jak wówczas błędnie osądzono), sprawiły, że w 1656 r. Pyskorski Zakład Odlewania Miedzi przestał działać (dotychczas przetwarzano tam 100 pudów miedzi rocznie). W $1723 \mathrm{r}$. w jego sąsiedztwie odnaleziono nowe złoża miedzi i zakład w roku następnym rozpoczął pracę na nowo, by po około 100 latach - w $1820 \mathrm{r}$. (według innych źródeł w 1829 r.), już po faktycznym wyczerpaniu się surowca w tym rejonie, zaprzestać całkowicie swej działalności (w tym ostatnim okresie zakład przetworzył ok. 157000 pudów miedzi rocznie) (MZU, 2001).

Warto zauważyć, że wpływ na ponowne uruchomienie wspomnianego powyżej zakładu pod koniec 1. ćw. XVIII w. miała inicjatywa wykazana przez pochodzącego z Holandii (według innych źródeł z krajów niemieckich) inżyniera wojskowego Georga Wilhelma de Hennina, zwanego w Rosji Wilhelmem Iwanowiczem de Henninem (Genninem), który wstąpił na carską służbę w $1698 \mathrm{r}$. Car Piotr I początkowo powierzył mu zarząd nad rosyjskimi zakładami odlewniczymi w Ołońcu (na terenie Karelii) produkującymi uzbrojenie na potrzeby wojska, a następnie wyznaczył go ,głównym administratorem spraw górniczych” i „głównym dyrektorem” zakładów produkcyjnych zlokalizowanych na Syberii. Za jego sprawą powstały słynne zakłady odlewnicze żelaza i miedzi 
w Kungurze, a sam W. de Hennin wspólnie z zasłużonym dla rozwoju górnictwa rosyjskiego kapitanem Wasilijem Tatiszczewem, uznawany jest za założyciela miasta. Pod jego kierownictwem wzniesiono też wiele twierdz zabezpieczających państwo od strony ziem zajmowanych przez plemiona baszkirskie i kirgiskie. Oprócz tego cudzoziemski inżynier sprawował nadzór nad sądownictwem syberyjskim. W. de Hennin był również autorem, bądź głównym redaktorem, fundamentalnej pracy poświęconej rozwojowi przemysłu i górnictwa pt. Opisanie uralskich i syberyjskich zakładów produkcyjnych (ĖSBE, 1892, 8, 343; RBI, 1914, 4).

Nie mniej jednak siłę napędową rozwoju rosyjskiego górnictwa i metalurgii, nastawionych przede wszystkim na produkcję na rzecz wojska, stanowili prywatni inwestorzy, rekrutujący się głównie spośród cudzoziemców ściągających na służbę carską z krajów Europy Zachodniej. W XVII w. pierwszoplanową rolę w tym zakresie zajmowali przedsiębiorcy kierujący zakładami metalurgicznymi zlokalizowanymi w Tule i jej okolicach (ryc. 1). Nie bez przyczyny XIX-wieczny rosyjski uczony Josif Gamel tak określił to miejsce: „Tuła jest kolebką sztuki zbrojeniowej w Rosji. W pobliżu tego miasta od najdawniejszych czasów była wydobywana ruda, z której odlewano żelazo, a z tego kowale tulscy wykuwali, oprócz innych rzeczy, wszelkiego rodzaju zbroje i broń" (Gamel', 1826).



Ryc. 1. Blok okolicznościowy „300 lat Tulskiego Zakładu Zbrojeniowego”, znaczek pocztowy, Rosja, $2012 \mathrm{r}$. (ru.wikipedia... Тульский..., 2018)

Fig. 1. Occasional block "300 years of the Military Factory in Tula", a stamp, Russia, 2012

(ru.wikipedia... Тульский..., 2018)

Właśnie tam, nad rzeczką Tulicą, przybyły z Holandii Andrzej Winius na początku lat 30. XVII w. założył pierwszy w Rosji zakład odlewający żelazne 
armaty i kule armatnie. Dzieło ojca, jednakże na znacznie większą skalę kontynuował jego syn Andrzej Winius, piastujący wiele różnorodnych wysokich stanowisk w centralnych urzędach państwowych (kierował m.in. Prikazem Aptekarskim - ówczesnym urzędem odpowiadającym dzisiejszemu ministerstwu - i był odpowiedzialny za funkcjonowanie poczty oraz pełnił funkcję tłumacza i dyplomaty carskiego podczas misji do krajów Europy Zachodniej). Kiedy w 1700 r. car Piotr I poniósł druzgocąca klęskę w bitwie ze Szwedami pod Narwą, w wyniku której przepadła niemal cała artyleria polowa i oblężnicza armii, Andrzej Winius (syn) otrzymał polecenie jej odbudowy w ,szybkim czasie”. $\mathrm{Z}$ powierzonego sobie zadania, pomimo wielu niesprzyjających okoliczności, wywiązał się w sposób zadowalający i walczący ze Szwedami żołnierze rosyjscy już wkrótce otrzymali zupełnie nowe i całkiem dobrej jakości różnego rodzaju działa (armaty, haubice i moździerze) oraz ręczną broń palną (Jurkin, 2007; Krokosz, 2010).

Zakłady wytwarzające broń w Tule, a także w innych miejscowościach, posiadali również przedstawiciele dwóch liczących się rodzin rosyjskich - Bataszewów i Demidowów (RBS, 1900, 2; Lubomirov, 1937). Jednakże, począwszy od panowania Piotra I, to kolejni członkowie tego drugiego rodu zajmujący się prowadzeniem wydobycia i przetwarzaniem rud żelaza zdołali sobie zdobyć pierwszoplanową pozycję. Wszystkiemu sprzyjała odpowiednia koniunktura związana $\mathrm{z}$ trwającą wojną północną oraz podjętymi przez władcę reformami państwowymi. Demidowowie prowadzący zlokalizowane w Tule i na Uralu kopalnie i zakłady produkujące nie tylko armaty oraz ręczną broń palną i białą, lecz także granaty, wnieśli wielki wkład w ostatecznie zwycięstwo wojsk carskich nad Szwecją, a także w modernizację rosyjskich sił zbrojnych zainicjowaną przez cara-reformatora (Kafengauz, 1949; Krokosz, 2010)5. Tulskie i uralskie manufaktury Demidowów pracowały także na potrzeby rosyjskiej floty wojennej (przede wszystkim okrętów operujących na Morzu Bałtyckim), dostarczając jej zarówno wszelkiego rodzaju armaty, a przede wszystkim tak potrzebne łańcuchy, kotwice i pozostałe żelazne części okrętów. Konkretne zamówienia trafiały również na potrzeby rozbudowującej się od $1703 \mathrm{r}$. w szybkim tempie w delcie rzeki Newy przyszłej stolicy Rosji - Sankt Petersburga. W ciągu XVIII i XIX w. Demidowowie, którzy dzięki swej działalności zdobyli ogromną fortunę, nie zapominali również o materialnym wsparciu rozwoju rosyjskiej nauki i kultury (Spasskij, 1833; Nazarevskij, 1893; Kafengauz, 1949). Warto jednak zauważyć, że cieszący się wielkim zaufaniem Piotra I Nikita Demidow, prowadząc swą działalność wielokrotnie łamał obowiązujące prawa i m.in. wbrew

\footnotetext{
${ }^{5}$ Produkowane w fabrykach Demidowów karabiny kosztowały zaledwie 1 rubla i 80 kopiejek, a w przypadku ich zakupu na terenie państw niemieckich cena ta wzrastała aż do 15 rubli.
} 
zakazom Kolegium Górnictwa prowadził wydobycie miedzi, podkupywał z zakładów skarbowych najlepszych specjalistów i wykwalifikowanych robotników, a także zatrudniał u siebie wziętych do niewoli jeńców szwedzkich (Golovščikov, 1881).

\section{Państwowa administracja górnicza}

Podjęte przez Piotra I dzieło modernizacji państwa wymagało ustanowienia stosownych organów administracyjnych odpowiedzialnych za wszelkie kwestie związane z górnictwem. W tym celu 24 sierpnia 1700 r. przy Prikazie Wielkiego Skarbu utworzono całkowicie nową instytucję Prikaz Spraw Górniczych ${ }^{6}$ : „(...) sprawy zlota i srebra i innych rud należy zarządzać okolniczemu Aleksiejewowi Timofiejewiczowi Lichaczowowi, i diakowi (urzędnikowi pracującemu w centralnych organach państwowych) Kuźmie Borinowi" (PSZRI, 1830, 4; Manin, 2011). Wyznaczony kierownikiem tego urzędu Aleksiej Lichaczow należał do starego moskiewskiego rodu szlacheckiego i w przeszłości piastował wiele funkcji nadwornych i państwowych. Za panowania cara Fiodora Aleksiejewicza (1676-1682) A. Lichaczow, wraz ze swym bratem Michaiłem i Iwanem Jazykowem, znalazł się w grupie osób wspierających tego władcę w toczącej się pomiędzy stronnictwami dworskimi rywalizacji o wpływy, a w konsekwencji o przejęcie władzy w Rosji. Okolniczy należał też do kręgu osób związanych z Fiodorem Rtiszczewem, działaczem państwowym zorientowanym na otwarcie się Rosji na kulturę zachodnioeuropejską, co przekładało się na jego zamiłowanie do literatury i kolekcjonowanie „ksiąg cudzoziemskich”. W tym kontekście można domniemywać, iż jego powołanie przez Piotra I w 1700 r. na stanowisko nadzorcy wszystkich kwestii górniczych w państwie nie było kwestią przypadkową (RBS, 1914, 10; Janin, 2004). 8 czerwca 1711 r., zgodnie z treścią rozporządzenia wydanego przez Senat Rządzący - instytucji zarządzającej niemal wszystkimi sprawami kraju ustanowionej przez Piotra I - Prikaz Spraw Górniczych (urząd ten był całkowicie związany z funkcjonowaniem struktur wojskowych o czym świadczy treść przywołanego dokumentu) został zlikwidowany, a jego kompetencje przekazano po części innym urzędom centralnym (Prikazowi Syberyjskiemu, Pałacowi Kazańskiemu czy Prikazowi Artylerii), po części władzom gubernialnym. $Z$ dokumentu wynika, że w urzędzie oprócz urzędni-

\footnotetext{
${ }^{6}$ Nazwę urzędu można oddać także jako Prikaz Spraw Kopalnianych.

${ }^{7} \mathrm{~W}$ hierarchii tytułów okolniczowie zajmowali drugie miejsce po bojarach. Uczestniczyli w organizowaniu ceremonii dworskich, asystowali carowi podczas audiencji udzielanych obcym posłom, w czasie podróży itp. Pełnili też wysokie funkcje zarówno w administracji państwowej, jak i w wojsku.
} 
ków rosyjskich (m.in. Daniło Woronow) pracowali również i cudzoziemscy specjaliści (m.in. Johann Friedrich Blüher), którym dano możliwość - razem z ich rosyjskimi uczniami i „przyrządami” - udać się do guberni syberyjskiej, gdzie odkryto rudy żelaza i srebra. W przypadku odkrycia takich złóż w innych regionach kraju, wspomniani ludzie mieli także zostać tam skierowani (PSZRI, 1830, 4; Manin, 2011). Piotr I likwidując Prikaz Spraw Górniczych zamierzał ustanowić w jego miejsce Kolegium Górnictwa, jednak tocząca się wojna i brak odpowiedniego przygotowania reformy całości centralnych urzędów administracji państwowej sprawiły, że zamysł ten musiał odłożyć na bardziej sprzyjający czas (Manin, 2011).

Powyższy stan nie trwał długo, gdyż 17 maja 1715 r. car polecił przywrócić na poprzednich zasadach Prikaz Spraw Górniczych z siedzibą w Sankt Petersburgu, zwany wówczas Kancelarią Spraw Górniczych lub Kancelarią Górniczą, a jego kierownictwo powierzył carewiczowi kasimowskiemu Iwanowi Wasiliewiczowi (PSZRI, 1830, 5). 8 lutego 1716 r. wszystkie kopalnie i zakłady odlewnicze w kraju zostały podporządkowane tej instytucji, a co za tym szło pod jej zwierzchność mieli powrócić wszyscy górniczy specjaliści. Do urzędu miała być także przekazana dokumentacja związana z eksploatacją wszystkich rud metali, gromadzona dotychczas przez administrację gubernialną. Reaktywowany urząd, podobnie jak było to wcześniej, miał być ściśle związany ze strukturami wojskowymi - „(...) dla posytek $i$ do spraw górniczych oddać z pozostajacych rezerwie 3 oficerów; a dla posytek także kapralstwo żotnierzy z Kancelarii Wojskowej". Oprócz tego oddelegowano tam 10 poddiaczych (urzędników pracujących w centralnych organach państwowych) i 2 stróżów. Na potrzeby Kancelarii Górniczej przewidziano również dodatkową subwencję w wysokości 100 rubli wyasygnowaną z funduszu Kancelarii Senatu (PSZRI, 1830, 5). Jak ustalił Michaił Kisieliew pierwszym urzędnikiem pracującym w nowo przywróconej instytucji był diak Łarion Protasow, wspierany przez 2 poddiaczych oddelegowanych z Kancelarii Senatu. W 1716 r. Kancelaria Górnicza zorganizowała kilka ekspedycji poszukiwawczych - urzędnicy i żołnierze udali się m.in. w okolice Saratowa i Astrachania skąd doniesiono o występowaniu tam pokładów rudy srebra oraz do powiatu Nowogrodzkiego, gdzie mieli zweryfikować informację o odnalezieniu pereł (Kiselev, 2009).

Wkrótce, bo już pod koniec 1717 r., nastąpiły gruntowne zmiany związane z funkcjonowaniem wszystkich najważniejszych organów administracyjnych państwa - zgodnie z decyzją cara dawne prikazy miały ulec ostatecznej likwidacji a w ich miejsce winny powstać instytucje zwane kolegiami. 11 grudnia 1717 r. opublikowany został carski dokument określający ich strukturę - w każdym mieli znajdować się zarówno Rosjanie, jak i cudzoziemcy. Dla pierwszych przewidziano następujące stanowiska: prezydenta, wiceprezydenta (tu dopuszczono też cudzoziemców), 4 radców kolegialnych, 4 asesorów kolegialnych, 
1 sekretarza, 1 notariusza, 1 registratora, 1 thumacza oraz pewną liczbę poddiaczych. Drugiej z grup zarezerwowano stanowiska: 1 radcy lub asesora, 1 sekretarza oraz pisarza ${ }^{8}$. Wolą władcy, rok 1718 miał zostać przeznaczony na organizację pracy wszystkich instytucji tak, aby rozpoczęly swą statutową działalność w 1719 r., przy czym w roku kolejnym na ich czele mieli stanąć nowi prezydenci (PSZRI, 1830, 5; Kiselev, 2015). 15 grudnia tego samego roku Piotr I wyznaczył prezydentów i wiceprezydentów kolegiów, powierzając Kolegium Górnictwa i Manufaktur naczelnikowi carskiej artylerii, generałowifeldcechmajstrowi (naczelnikowi artylerii rosyjskiej) Jakubowi Bruce'owi (PZSRI, 1830, 5; ryc. 2). Należy zauważyć, że według pierwotnego projektu sprawy związane „manufakturami” miały znaleźć się w gestii Kolegium Handlu, w którego kompetencji były „podatki pobierane od wszelakiego handlu”



Ryc. 2. Portret Jakuba Wilimowicza Bruce'a, autor nieznany, 1. poł. XVIII w.

(ru.wikipedia... Брюс..., 2018)

Fig. 2. Iakov Vilimovich Bruce, portrait, author unknown, 1 st half of the $18^{\text {th }}$ century (ru.wikipedia... Брюс..., 2018)

i zwierzchność sądownicza nad „handlowcami”. Decyzja o powołaniu „,górniczej" instytucji została podjęta, lecz brakowało jeszcze odpowiedniego aktu normatywnego regulującego jej funkcjonowanie, co też zauważył sam jego prezydent, generał-feldcechmajster Jakub Bruce w liście do odpowiedzialnego za reformę administracji generała-majora Pawła Jagużyńskiego ze stycznia 1718 r.: „Jego Carska Wysokość raczyt wyznaczyć prezydentów, którzy maja znaleźć się w tych kolegiach, $i$ aby oni do końca roku je przygotowali i należne informacje $z$ tym zwiazane zbierali. $Z$ nich ani jeden o porzadkach $w$ owych

\footnotetext{
${ }^{8} \mathrm{~W}$ dokumencie pisarza określono mianem „szkriejwier” (ros. шкрейвер).
} 
kolegiach, i czym się w nich zajmować, nie wie”. Prezydent Kolegium Górnictwa nie krył także swego niezadowolenia $\mathrm{z}$ całokształtu zamierzonej reformy urzędów państwowych, która w swych założeniach bazowała na wzorcach szwedzkich (Kiselev, 2015; Manin 2011). Wdrożeniu zmian we w całym aparacie administracji państwowej nie sprzyjała również sytuacja międzynarodowa, gdyż Rosja nadal była uwikłana w wojnę ze Szwecją. Dotyczyło to przede wszystkim instytucji powierzonej J. Bruce'owi, ponieważ w roku przypadającym na jej organizację Piotr I wyznaczył jej prezydenta swym przedstawicielem na rosyjsko-szwedzki kongres pokojowy obradujący na Wyspach Alandzkich (Fejgina, 1859).

Pomimo różnorodnych trudności, przede wszystkim związanych ze skompletowaniem odpowiednio kompetentnej kadry urzędniczej, pod koniec sierpnia 1718 r. Kolegium Górnictwa i Manufaktur, mogło przystąpić do rozpoczęcia swej działalności (Amburger 1966). Wśród służących tam osób pierwszoplanową rolę odgrywali dotychczasowi podkomendni J. Bruce'a służący dotychczas $\mathrm{w}$ artylerii. Trafiali tam również ludzie związani już z górnictwem i metalurgią, m.in. 7 diaków z ulegającej właśnie likwidacji Kancelarii Górniczej, czy też pochodzący z Saksonii „mistrz probierczy” J. Blüher, który pracował w Rosji od 1699 r., bądź żołnierze, głównie oficerowie, armii, m.in. podpułkownik artylerii Aleksiej Zybin (późniejszy prezydent tego urzędu w latach 1726-1731), kapitan-porucznik pułku Siemionowskiego książę Wasilij Wołkoński, porucznik rozwiązanych pułków liniowych Iwan Biełoutow czy syn pisarza wojskowego Iwan Suworow. W 1719 r. służbę rozpoczął tam pochodzący ze Szwajcarii asesor Henryk Schlatter, a cztery lata później do prac przyjęto tam także jego syna Iwana (Johanna) Schlattera, późniejszego wybitnego specjalistę w zakresie górnictwa, metalurgii oraz mennictwa (Gel'big, 1886; Bal'zer, 1844; Bugrov, 2012). Wśród urzędników instytucji znalazł się również wzięty do niewoli, w zwycięskiej dla Rosjan bitwie pod Połtawą w 1709 r., audytor armii szwedzkiej Wincent Reiser, który dwa lata później wstąpił na służbę w carskiej artylerii. Odpowiednie doświadczenie zawodowe połączone ze znajomością języków: szwedzkiego, niemieckiego i rosyjskiego, sprawiły, iż urodzony w Hamburgu cudzoziemiec stał się dla J. Bruce'a osobą niezbędną w powstającym kolegium (Gel'big, 1886; Kiselev, 2015; RBS, 1910, 15).

Od stycznia 1719 r. w Kolegium Górnictwa i Manufaktur zaczęto prowadzić protokoły. Pod koniec maja tego roku obsadzona była już większość stanowisk instytucji. Prezydentem pozostawał nadal J. Bruce, łącząc swe obowiązki z dalszym kierowaniem spraw dotyczących artylerii, asesorami zostali W. Reiser i H. Schlatter, a kierownikiem kancelarii został diak L. Protasow, któremu podlegał 1 registrator i 7 poddiaczych (1 wyższy, 4 średnich, 2 młodszych). Bez określonego zajęcia pozostawał książę W. Wołkoński, a także A. Zybin, który z kolei oficjalnie pełnił funkcję ober-komisarza w Kancelarii Artyleryjskiej. 
Oprócz tego do prac w kolegium oddelegowano 4 emerytowanych oficerów - 3 kapitanów i 1 porucznika. Natomiast służbę wartowniczą i kurierską pełnić tam miało 2 kaprali i 18 emerytowanych (starszych wiekiem) dragonów i żołnierzy. Wynagrodzenie w kolegium otrzymywał również J. Blüher oraz jego thumacz Paweł Briwcyn. Ostatni z wymienionych należał także do grona osób zajmujących się poszukiwaniem nowych rud metali na terenie Rosji (Kiselev, 2015; Kurlaev, 2016). Nie można zapomnieć również o niezwykle zasłużonym dla rozwoju rosyjskiego górnictwa wspomnianym kapitanie artylerii W. Tatiszczewie, który od lat 20. XVIII w. był przedstawicielem kolegium na Uralu (Ûht, 1985). W lipcu 1720 r. wyposażony w pełnomocnictwa wydane przez samego cara i Kolegium Górnictwa, wraz z innymi specjalistami, przybył on do Kunguru i Uktusu, aby objąć całościowy nadzór nad rozwojem tamtejszego górnictwa. W. Tatiszczew oprócz podjęcia kroków zmierzających do wznowienia działalności miejscowego zakładu produkcyjnego (ryc. 3), miał również prowadzić dochodzenia $\mathrm{w}$ spornych sprawach finansowych pomiędzy przemysłowcami, a także sprawdzić sprawy związane z nadużyciami skarbowymi, jakich dopuszczał się gubernator Syberii Matwiej Gagarin (śledztwo w jego sprawie trwało od 1714 r.) (German, 1810; Kurlaev, 2016). Równie ważnym zadaniem powierzonym W. Tatiszczewowi było założenie przy tamtejszych zakładach produkcyjnych placówki edukacyjnej, przysposabiającej młodych ludzi do przyszłych

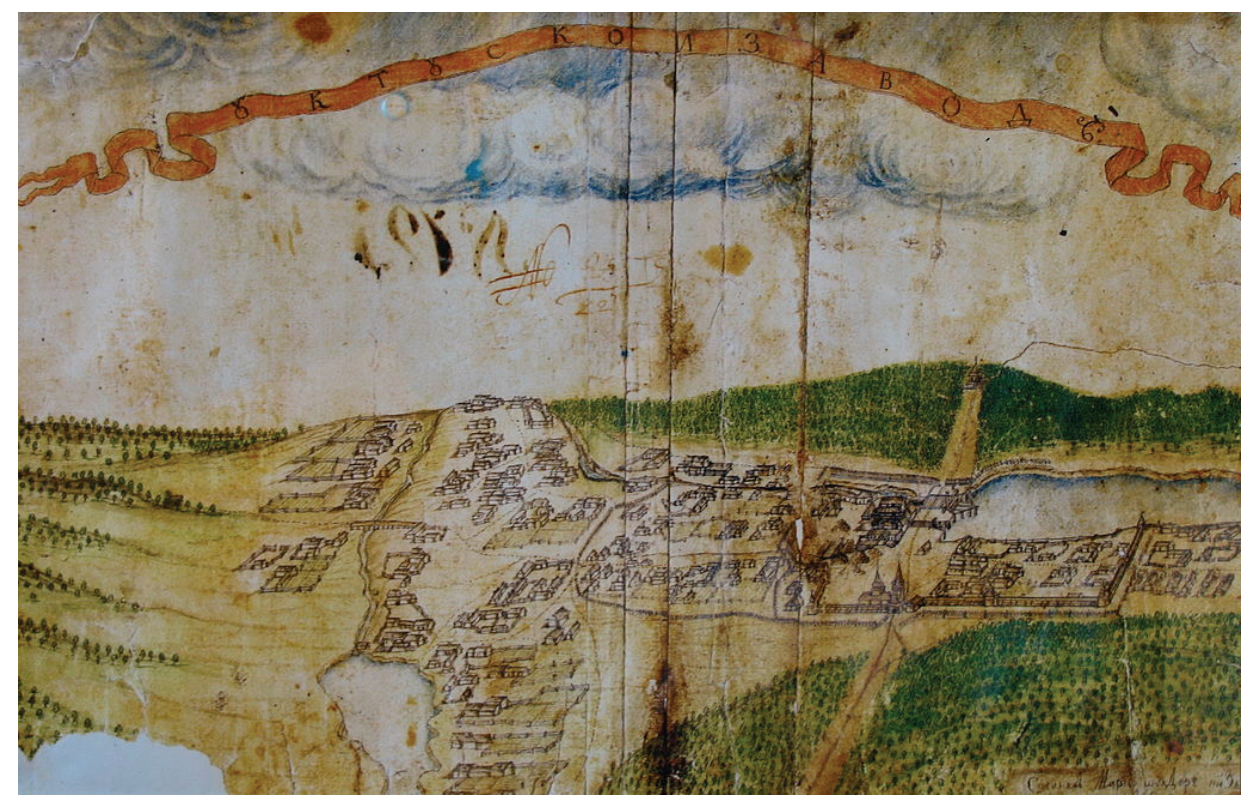

Ryc. 3. Zakład produkcyjny w Uktusie w latach 20. XVIII w. (ru.wikipedia... История..., 2018) Fig. 3. Metallurgy factory in Uktus in 1720s (ru.wikipedia... История..., 2018) 
prac w Kolegium Górnictwa. W tym celu zabrał on ze sobą 4 najlepszych adeptów moskiewskiej Szkoły Artyleryjskiej, którym zamierzał powierzyć funkcje nauczycieli. Już na miejscu, po rozpoznaniu sytuacji, poinformował swych przełożonych, że będzie się starał o uczniów spośród miejscowej młodzieży szlacheckiej i urzędniczej (synów poddiaczych), którzy nie zostali jeszcze wysłani na naukę do Sankt Petersburga. Latem 1721 r. w Kungurze i Uktusie naukę „spraw górniczych” rozpoczęli pierwsi uczniowie w liczbie 27 i 29, rekrutujący się również z innych niż szlachta i urzędnicy grup społecznych. W. Tatiszczew, za zgodą Kolegium Górnictwa kierował do nauki także sieroty, którym zapewniał wyżywienie i pieniądze na odzież. W 1723 r. z uwagi na spór z rodziną Demidowów został odwołany do stolicy, lecz zapoczątkowane przez niego dzieło edukacji w zakresie górnictwa - już w założonym w tym samym roku Jekaterynburgu - kontynuował przybyły na miejsce W. de Hennin (German, 1810; Gel'big 1886; Matvejčuk, 2014).

Podstawą prawną utworzenia Kolegium Górnictwa i Manufaktur było rozporządzenie carskie z 10 grudnia 1719 r. (Jurkin, 2013a). Z racji swej wymowy wstęp i znajdujące się po nim 17 punktów, które w jasny sposób precyzowały kto i na jakich zasadach ma prawo do poszukiwań, wydobywania i przetwarzania rud metali oraz minerałów, określane były również mianem „przywileju górniczego” lub „wolności górniczej”. Już na samym początku swej woli Piotr I odniósł się do dotychczasowych zaniedbań w kwestiach górniczych w Rosji: „Ponieważ My najmiłościwiej dostrzegliśmy, że dzięki przedsiębiorstwom górniczym i ich odpowiedniemu założeniu, ziemia się wzbogaca i rozkwita; także puste i jałowe miejsca zasiedlają się ludźmi, co też i doświadczenie w rozlicznych ziemiach dobitnie pokazuje. Nasze też Państwo Rosyjskie, przed wieloma innymi krajami, przoduje i jest zasobne w wielką ilość potrzebnych tak metali jak i minerałów, które do obecnego czasu bez żadnej gorliwości były poszukiwane; co więcej nie były one tak używane, jak należy tak, że wielka korzyść i przybytek, które by Nam i Naszym poddanym z tego wyniknąć mogły były w pogardzie". W dalszej części dokumentu władca wyjaśniał, że taki stan rzeczy spowodowany był brakiem zrozumienia znaczenia spraw kopalnianych oraz tym, iż przedsiębiorcy obawiali się odebrania - przez władze skarbowe - uruchomionych inwestycji (kopalni, zakładów przetwórczych). W tym też właśnie celu, aby państwo osiągało korzyści z górnictwa zostało utworzone Kolegium Górnictwa, które miało „(...) być jedynym sędzia nad wszystkimi do tego należacymi sprawami i osobami, aby w żaden sposób gubernatorzy, wojewodowie, czy nizej postawieni naczelnicy $w$ sprawy górnicze nie mieszali się $i$ nie przeszkadzali, chyba że to Kolegium Górnictwa, lub przez niego wyznaczeni urzędnicy, jakiejś pomocy od innych potrzebować będa”. Kolegium miało jako pierwsze wydawać rozporządzenia jak należy zakładać kopalnie i przedsiębiorstwa, a ludzie chcący zabrać się za te kwestie mieli zostać „obdarzeni” przywi- 
lejami ujętymi w 17 punktach. Już pierwszy z nich dawał prawo każdemu człowiekowi, bez względu na przynależność stanową, prowadzić poszukiwania, odlewać oraz „warzyć" metale i surowce ziemne: złoto, srebro, miedź, cynk, ołów, żelazo, a także minerały, jak saletrę, siarkę i kamienie, zarówno na swojej jak i na cudzej ziemi. Nie ograniczono przy tym liczby potrzebnych do pracy robotników. Zgodnie z punktem 2 każdy kto znalazł „nowe metale” i chciał je przetwarzać, musiał przybyć do Sankt Petersburga do Kolegium Górnictwa, lub do wyznaczonych przez niego oficerów rezydujących w Moskwie, Kazaniu i na Syberii, aby otrzymać „dobrą radę”, a przede wszystkim złożyć stosowne pismo o pozwolenie na rozpoczęcie działalności. Oprócz tego do instytucji winna być dostarczona próbka danej rudy żelaza (pkt. 2 i 3). Obowiązkiem kolegium było działać bez zwłoki i poinstruować jak eksploatować daną rudę lub minerał (pkt. 4) oraz wydać zezwolenie na wydobycie, przy czym wielkość pola wydobywczego została ściśle określona i wynosiła 250 na 250 sążni $^{9}$ (pkt. 5). Punkt 6 przewidywał pierwszeństwo do zakładania przedsiębiorstw właścicielom ziemi gdzie występowała dana ruda - dotyczyło to zarówno właścicieli pomiestji (dóbr beneficjalnych), jak i wotczyn (dóbr alodialnych). W przypadku kiedy właściciel ziemi z jakiś powodów (głównie z braku pieniędzy) nie mógł, czy też nie chciał, samodzielnie czy ze wspólnikami prowadzić wydobycia, to musiał się liczyć, że eksploatację tam podejmą inni przedsiębiorcy. Naturalnie mogło to nastąpić tylko po zapłaceniu właścicielowi ziemi zapłaty w wysokości $1 / 32$ dochodu od zysków z każdej rudy i każdego minerału. „Rozsądną cenę” miano także ustalić za drewno lub węgiel znajdujące się na tej ziemi, które potrzebne było do uruchomienia i pracy zakładu (pkt. 7). Szczególną opieką i wsparciem finansowym kolegium cieszyli się „ochotnicy” zamierzający poszukiwać i przetwarzać rudy złota, srebra lub miedzi (pkt. 8). Instytucja wspierała również wszystkich, którzy rozpoczną wydobycie przynoszące zysk w dość krótkim czasie (pkt. 9). Wszyscy „mistrzowie” (specjaliści) podejmujący prace w górnictwie byli automatycznie zwolnieni od poboru do służby w wojsku i flocie oraz podatków, przy czym za swoją pracę mieli otrzymywać wynagrodzenie (pkt. 10). Przedsiębiorcy zostali również zobowiązani do wniesienia opłaty na potrzeby Kolegium Górnictwa w wysokości $1 / 10 \mathrm{z}$ osiąganego zysku. W przypadku strat przedsiębiorstwa car obiecywał ,na ileś lat zawiesić” ową opłatę (pkt. 11). Ponadto władca warował sobie pierwszeństwo zakupu wydobytych rud: złota, srebra, miedzi i saletry przed innymi kupcami. Skupem mieli zająć się ludzie oddelegowani przez Kolegium Górnictwa (pkt. 12), a obydwie strony powyższych transakcji miały mieć gwarancję stosownych zysków (pkt. 13), przy czym gdyby urzędnicy państwowi nie mieli przy sobie na tyle pieniędzy, aby w ciągu miesiąca zapłacić za „gotowe złoto, srebro, miedź i saletrę”, wówczas przemy-

\footnotetext{
${ }^{9}$ Sążeń $=213,36 \mathrm{~cm}$.
} 
słowiec miał prawo sprzedać je komu tylko chciał (pkt. 14). Pozostałe metale jak żelazo, ołów, cynk oraz inne minerały mogły być swobodnie sprzedawane przez wytwórcę, przy czym saletrę „niepotrzebną” carowi mógł on sprzedawać za granicę jedynie za pozwolenia Kolegium Górnictwa (pkt. 15). Ostatnie dwa punkty - 16 i 17 - mówiły o konieczności funkcjonowania kopalni i zakładów w oparciu o wydane przywileje, co gwarantowało spodziewane korzyści państwu i przedsiębiorcom. W punkcie 17 dodatkowo podkreślono, że żaden $\mathrm{z}$ carskich poddanych nie miał prawa zataić przed władzami górniczymi gdzie znajdują się rudy żelaza - winowajca mógł spodziewać się kar cielesnych, konfiskaty majątku lub kary śmierci (PSZRI, 1830, 5).

Utworzenie Kolegium Górnictwa i Manufaktur było dla władz rosyjskich pierwszym krokiem na drodze do rozwoju górnictwa, a co za tym szło ogólnej gospodarki rosyjskiej. Piotr I miał świadomość, iż w kraju znajduje się znikoma liczba osób znająca się na tych kwestiach i w związku z powyższym po raz kolejny postanowił sięgnąć po przybyszy zza granicy. Już 30 lipca 1720 r. car wydał manifest do cudzoziemców, zapraszając ich do prowadzenia wydobycia rud żelaza i minerałów oraz prowadzenia zakładów przemysłowych, na tych samych prawach co Rosjanie (powołał się przy tym wyraźnie na swe rozporządzenie z 10 grudnia 1719 r. regulujące działalność Kolegium Górnictwa i Manufaktur). Obcokrajowcom prowadzącym działalność górniczą w Rosji zagwarantowano pierwszeństwo zakupu ich produkcji przez władze skarbowe (PSZRI, 1830, 6; German, 1810). Na tym tle niezwykle interesująco przedstawia się nigdy nie zrealizowana koncepcja ściągnięcia do prac górniczych powstałej jeszcze w 1684 r. francuskiej Kompanii Missisipi ${ }^{10}$, wchłoniętej w 1717 r. przez nowo utworzoną Kompanię Zachodnią (Mošenskij, 2015). 13-punktowy projekt kontraktu przewidujący „pomnożenie rosyjskich zakładów górniczych” zawarto w Paryżu w 1720 r. Zasadnicza treść dokumentu spisanego w stolicy Francji w zasadzie nie odbiegała od postanowień „przywileju górniczego” z 19 grudnia 1719 r. i dopełniającego go rozporządzenia z 23 stycznia roku następnego oraz wspomnianego manifestu carskiego zapraszającego cudzoziemców do przyjazdu do Rosji (pkt. 1-4, 6, 12). Jednakże Kompanii Missisipi zagwarantowano znacznie więcej przywilejów i znacznie większy zakres pomocy ze strony Kolegium Górnictwa i Manufaktur niż innym przedsiębiorcom z branży. Co więcej, w myśl punktu 9, ludzie pracujący dla kompanii znajdowali pod osobistą protekcją cara. Inicjatywa francuska została również zwolniona $\mathrm{z}$ opłat ceł - morskiego i lądowych oraz akcyzy, a przy swoich zakładach mogła urucho-

\footnotetext{
${ }^{10}$ Początkowo Kompania Missisipi posiadała własne okręty i trudniła się dochodowym handlem tytoniem, lecz w 1717 r. znajdowała się już na skraju bankructwa i została przejęta przez wspomnianą Kompanię Zachodnią, utworzoną w celu eksploatacji bogactw naturalnych należącej wówczas do Francji Luizjany.
} 
mić na swoje potrzeby warzelnie piwa (pkt. 8). Przewidywano, że kompania będzie chciała mieścić się jak najbliżej stolicy rosyjskiej, dlatego nie czyniono przeszkód, aby swoje zabudowania wzniosła „nad Newą”, czyli w Sankt Petersburgu. Jej pracownikom zagwarantowano także swobodę kultu religijnego (pkt. 10). W przypadku rozpoczęcia działań na terenie Rosji kompanii zapewniono znaczną autonomię. Na jej czele miał stać ober-dyrektor od ,spraw górniczych", wyposażony w prawo sądzenia podległych sobie pracowników w zakresie „spraw prywatnych”, z wyłączeniem ,przewinień górniczych”, które rozsądzało Kolegium Górnictwa i Manufaktur. Ober-dyrektor zarządzał też mieniem zmarłych członków kompanii. Przy opisie ustanawiającym ten urząd nadmieniono, że na „potrzeby górnicze” - zapewne na jego wniosek - mieli być kierowani górnicy i oficerowie, po uprzednim zaprzysiężeniu w Kolegium Górnictwa i Manufaktur (pkt. 5, 7, 11). Dokument został podpisany 13 stycznia $1721 \mathrm{r}$. przez J. Bruce'a oraz trzech członków urzędu: Johanna Martina Michaelisa, A. Zybina, W. Reisera (PSZRI, 1830, 6; German, 1810) ${ }^{11}$.

Pierwsze lata działalności Kolegium Górnictwa i Manufaktur nie należały do łatwych. Mimo wszystko znacznie wówczas wzrosła ranga samej instytucji, ponieważ decyzją władcy z 12 stycznia tego 1722 r. jej prezydent otrzymał prawo do zasiadania w posiedzeniach Senatu Rządzącego (PSZRI, 1830, 6). Jednakże pomimo opublikowania i wprowadzenia w życie „przywileju górniczego" poszukiwanie rud metali i minerałów oraz zakładanie nowych przedsiębiorstw napotykało szereg trudności. Szczególnie dotkliwy okazał się brak podstawowej kadry robotniczej. W związku z powyższym, już znacznie wcześniej, bo 29 października 1720 r. prezydent Kolegium Wojskowego Aleksander Mienszykow polecił opublikować wolę cara, zgodnie z którą informacje o wszystkich zbiegłych lub uchylający się od służby wojskowej rekrutów z guberni Syberyjskiej miały być przekazywane z pułków ich przydzielenia do Kolegium Górnictwa (PSZRI, 1830, 6). Nie mniej kłopotów nastręczały kwestie związane z nielegalną produkcją i kradzieżą gotowych produktów, celowym ukrywaniem przed władzami górniczymi złóż rud metali i minerałów, a także z podrabianiem pieniędzy. W celu zapobiegania nielegalnej produkcji żelaza Kolegium Górnictwa, na polecenie cara, w rozporządzeniu z 6 kwietnia 1722 r. określiło sposoby ce-

\footnotetext{
${ }^{11}$ W 1719 r. Kompania Zachodnia wchłonęła trzy inne francuskie korporacje handlowe - Kompanię Wschodnioindyjską, Kompanię Chińską oraz Kompanię Afrykańską, uzyskując tym samym monopol handlu na terenach ich działalności. Kierownictwo tak silnej korporacji, zwanej Kompanią Indyjską, połączoną z niedawno utworzonym Bankiem Królewskim, objął sam John Law, szkocki ekonomista, któremu we Francji powierzono stanowisko Generalnego Kontrolera Finansów. Połączenie Kompanii Indyjskiej z Bankiem Królewskim w jedną firmę miało przynieść zarówno skarbowi państwa, jak i prywatnym inwestorom stosowne zyski z handlu zamorskiego. Tak się jednak nie stało, gdyż już w 1720 r. doszło do krachu finansowego połączonych instytucji, a następnie do dymisji Johna Lawa.
} 
chowania żelaza (PSZRI, 1830, 6). Jeszcze w tym samym roku, 19 kwietnia, Kolegium Górnictwa zostało zobowiązane do prowadzenia śledztw w związku z donosami o ,przeszkodach wynikłych w poszukiwaniu rud”, za którymi mieli stać urzędnicy państwowi oraz właściciele ziem gdzie znajdowały się bogactwa naturalne (PSZRI, 1830, 6). 28 sierpnia 1722 r. car ponownie polecił Kolegium Górnictwa prowadzenie dochodzenia w związku z niedopuszczeniem do poszukiwań rud metali, a także kradzieżą srebra i fałszowaniem monet (PSZRI, 1830, 6).

Często okazywało się, że urzędnicy Kolegium Górnictwa byli bezsilni w sytuacjach kiedy próbowali dokonywać kontroli kopalni i zakładów produkcyjnych należących do wpływowych inwestorów. Swoistym przykładem stał się konflikt reprezentującego instytucję W. Tatiszczewa oraz wspierającego go J. Blühera z rodem Demidowów. Już w grudniu 1720 r. Nikita Demidow otrzymał z Kolegium Górnictwa kilka wezwań polecających mu wyjaśnić i uregulować różne kwestie dotyczące prowadzonej działalności wydobywczo-produkcyjnej. Jedno dotyczyło spraw własnościowych zakładów i dziedziczenia nieruchomości przez jego syna Akinfija. Inne wezwanie miało charakter kontrolno-doradczy, gdyż precyzowało w jaki sposób N. Demidow miał rozdzielać wydobywaną przez siebie rudę do poszczególnych zakładów przetwórczych, tak by żaden $\mathrm{z}$ nich nie przynosił strat. Znacznie poważniejsze było wezwanie z 1721 r., w którym pojawił się zarzut opóźniania dostaw gotowego surowca na rzecz państwa. W tym wypadku jednak N. Demidowowi nie udało się dowieść celowego działania, gdyż sytuacji sprzyjał swoisty bałagan związany z prowadzeniem i egzekwowaniem tego typu zamówień przez władze skarbowe. Równie poważnym zarzutem było oskarżenie go o uchylanie się od płacenia podatku przewidzianego przez „przywilej górniczy”. Niewyjaśniona pozostawała również sprawa związana ze ściąganiem przez niego do swoich dóbr chłopów pracujących uprzednio w zakładach skarbowych. Zdecydowany opór urzędników N. Demidowa odnośnie podporządkowania się urzędnikom Kolegium Górnictwa prowadzącym dochodzenia sprawił, że do sporu włączył się sam car, który w 1722 r. polecił przedsiębiorcy i W. Tatiszczewowi stawić się w Moskwie w celu wyjaśnienia zaistniałych ,niedomówień”. Ostatecznie kapitan artylerii został wyłączony z dalszego postępowania, a jego miejsce zajął W. de Hennin. Wszystko wskazuje, że monarcha okazał się łaskawy wobec wielkiego producenta, zapewniającego regularne dostawy tak potrzebnego żelaza i miedzi dla lądowych i morskich sił zbrojnych (German, 1810; Ûrkin, 2013a; Matvejčuk, 2014). Jak wielką wagę car-reformator przywiązywał do zaopatrzenia floty w gotowy „sprzęt wojskowy” świadczy na przykład decyzja o skierowaniu w styczniu 1724 r. do ochrony odlewających kotwice zakładów w Siestoriecku 1 roty żołnierzy. Oprócz tego miał tam znajdować się ,sztab biurowy” prowadzony przez wojskowych oraz specjalnie oddelegowani na ich potrzeby - lekarz 
i chirurg (PSZRI, 1830, 7). W następnym miesiącu manufaktury te przekazano pod bezpośrednią kontrolę Kolegium Admiralicji (PSZRI, 1830, 7). Warto nadmienić, że w 1724 r. Kolegium Górnictwa zajmowało się i nadzorowało odbywający się w mennicach państwowych skup złota i srebra od osób prywatnych, z przeznaczeniem tych kruszców na bicie pieniędzy; kupno złota miano prowadzić tylko do kwietnia tego roku (PSZRI, 1830, 6).

Jak już nadmieniono, w proces rozwoju rosyjskiego górnictwa od samego początku zaangażowani byli liczni cudzoziemcy, przede wszystkim specjaliści pochodzący z krajów niemieckich (głownie z Saksonii), znający się na poszukiwaniu i eksploatacji rud metali (w zakresie solnictwa wykwalifikowaną kadrę stanowili rosyjscy „mistrzowie” wywodzący się m.in. ze Starej Russy, Soli Wyczegodzkiej czy Totmy). Wspomnieć należy, że zachodnioeuropejskich specjalistów różnych branż, w tym lekarzy, sukienników oraz górników zapraszał do siebie już w 1600 r. car Borys Godunow (Akty istoričeskie..., 1941, 2). W tej kwestii nic nie uległo zmianie także za panowania Piotra I, który starał się też korzystać z kilkusetletniego doświadczenia i tradycji górniczych państw Europy Zachodniej. W tym celu w latach 1702-1704 wysłano z Rosji do Saksonii 10 ludzi, aby tam uczyli się „sztuki górniczej”. W 1719 r. przywołany już W. de Hennin na polecenie władcy udał się z misją do Prus, Saksonii, Holandii, Francji i Anglii, aby na miejscu przyjrzeć się tamtejszym kopalniom i zakładom produkcyjnym. Carski wysłannik podczas swego pobytu na Zachodzie miał sporządzać ich plany i modele znajdujących się tam urządzeń i maszyn (Bogdanova, 1932). Potrzeba wykwalifikowanej kadry górniczej - mogącej pracować zarówno w Kolegium Górnictwa, jak i przy innych inwestycjach - była na tyle paląca, że w 1720 r. Piotr I po raz kolejny zdecydował się wydać manifest zapraszający cudzoziemców do przyjazdu do Rosji (German, 1810). Nie próżnował również W. Taiszczew, który w 1724 r. już w randze pułkownika udał się z tajną misją do Szwecji, gdzie miał zapoznać się z funkcjonowaniem tamtejszego górnictwa i przeprowadzić akcję werbunkową wśród szwedzkich specjalistów do pracy w Rosji. W 1725 r. do przebywającego w Szwecji W. Tatiszczewa wysłano grupę uczniów rosyjskich szkół - Artyleryjskiej i Nawigacji, aby na miejscu od Szwedów uczyli się pracy w górnictwie. W 1728 r. część z nich, pod odbyciu tego swoistego kilkuletniego stażu zagranicznego, zostało skierowanych do prac na Uralu (Bogdanova, 1932; Berh, 1828). Należy nadmienić, że większość cudzoziemców z krajów Europy Zachodniej, które podejmowały prace w rosyjskich instytucjach oraz kopalniach i zakładach produkcyjnych było wyznania luterańskiego, m.in. J. Blüher, W. de Hennin, J. Michaelis. Z uwagi na fakt, że wydobycie rud metali koncentrowało się wówczas na Uralu protestanccy specjaliści górniczy skupieni byli w prężnie działającej gminie luterańskiej, jaka powstała w Jekaterynburgu (Andreev, 2010; ryc. 4). 


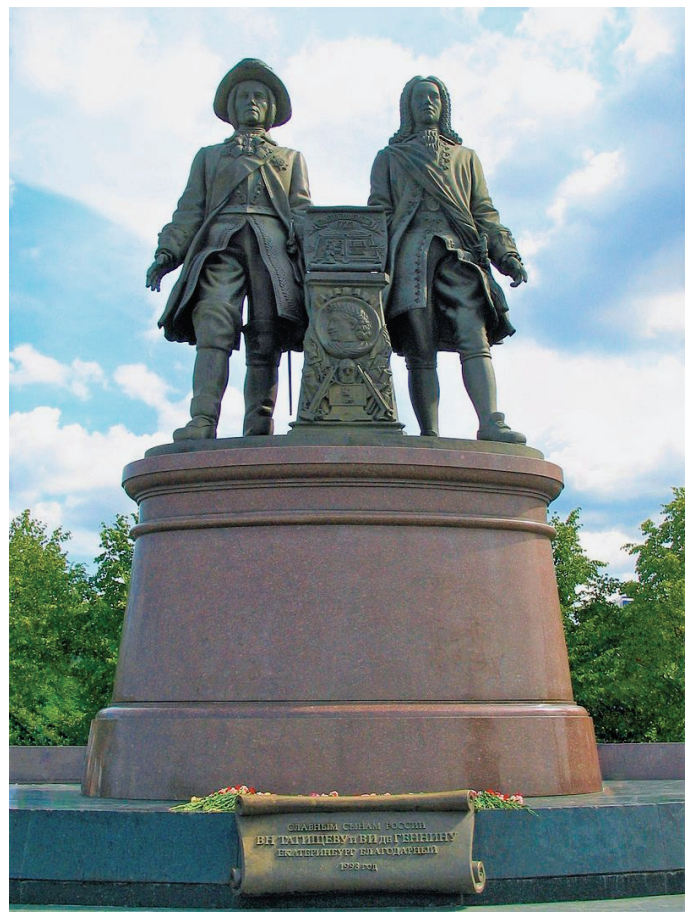

Ryc. 4. Jekaterynburg, pomnik założycieli miasta

- Wasilija Tatiszczewa i Georga Wilhelma de Hennina;

arch. P. Czusowitin, 1998 r. (ru.wikipedia... Екатеринбург..., 2018)

Fig. 4. Yekaterinburg, the monument of the founders of the city - Vasily Tatishchev and Georg Wilhelm de Hennin; architect P. Chusovitin, 1998 (ru.wikipedia... Екатеринбург..., 2018)

W styczniu 1725 r. zmarł car Piotr I, lecz zapoczątkowane przez niego dzieło rozwoju rosyjskiego górnictwa było kontynuowane przez jego następców. Szczególną uwagę sprawom górniczym poświęcono za panowania carowej Anny Iwanownej (1730-1740). W 1731 r. działające osobno od 1722 r. Kolegium Górnictwa i Kolegium Manufaktur zostały włączone do Kolegium Handlowego jako jego agendy (tzw. ekspedycje). W 1733 r. prace rozpoczęła specjalna komisja, rozpatrująca czy utrzymywanie skarbowych kopalni i zakładów produkcyjnych jest rentowne i czy nie lepiej przekazać je na określonych warunkach jednemu wielkiemu, bądź kilku mniejszym inwestorom prywatnym. Na dopuszczenie do kierowania częścią skarbowych przedsiębiorstw przez osoby prywatne i kompanie zgodzono się dopiero w 1739 r. Trzy lata wcześniej, w 1736 r., zdecydowano się także na likwidację Kolegium Górnictwa, ustanawiając w jego miejsce urząd zwany Dyrektoriatem Górnictwa (oficjalna nazwa instytucji brzmiała: Generalny-Berg-Dyrektoriat), na czele którego stanął pochodzący z Saksonii baron Kurt 
Alexander von Schönberg. Wkrótce cudzoziemiec związany z kręgami władzy stał się największym przedsiębiorcą górniczym w Rosji. Nastąpiło to m.in. za sprawą wydanego przez carową Annę Iwanowną 3 marca 1739 r. przywileju powołującego do życia Kompanię Górniczą, zajmującą się eksploatacją rud żelaza w Laponii i Wierchoturiu. Zgodnie z treścią liczącego 9 punktów dokumentu o wszystkim co było związane $\mathrm{z}$ wydobyciem rud żelaza na określonych terenach oraz ich przetwórstwem znalazło się w gestii K. von Schönberga, nadzorującego utworzoną właśnie Kompanię Górniczą (PSZRI, 1830, 10; Bogdanova, 1932; Amburger, 1966; Bakšaev 2005). Także 3 marca 1739 r. wszedł w życie Regulamin górniczy, stanowiący swoiste dopełnienie do obowiązującego ,przywileju górniczego" wydanego przez Piotra I. Dokument ten był również podstawą powołania Kompanii Górniczej i uczynienia z K. von Schönberga najpotężniejszego w kraju przedsiębiorcy górniczego (PSZRI, 1830, 10; Manin, 2016). W 1742 r. decyzją carowej Elżbiety Piotrownej (1741-1761), córki Piotra I, Dyrektoriat Górniczy, a także utworzone w 1739 r. Biuro Górnicze w Archangielsku, zostały zniesione i ponownie przywrócono do życia niezależne od siebie urzędy - Kolegium Górnictwa i Kolegium Manufaktur. Stojący na czele Dyrektoriatu Górnictwa i czerpiący zyski finansowe uzyskiwane przez Kompanię Górniczą K. von Schönberg został pozbawiony swych stanowisk i aresztowany oraz oskarżony za przywłaszczenie pieniędzy skarbowych. Ostatecznie rok później Saksończyk został odesłany z powrotem do swej ojczyzny (PSZRI, 1830, 11; Bogdanova, 1832; Amburger, 1966).

Odnowione przez Elżbietę Piotrowną Kolegium Górnictwa, nawiązujące do formy określonej mu przez Piotra I, przetrwało do 1783 r. kiedy za sprawą carowej Katarzyny II (1762-1796) część jego uprawnień przeniesiono do kilku innych urzędów, a samą instytucję przemianowano na Ekspedycję do Spraw Górniczych (PSZRI, 1830, 21). Stan taki przetrwał jedynie kilkanaście lat, gdyż w 1796 r. za sprawą cara Pawła I (1796-1801), burzącego reformy wprowadzone przez matkę, Kolegium Górnictwa zostało przywrócone po raz kolejny (PSZRI, 1830, 25). W 1806 r. instytucja została przemianowana na Departament Górnictwa podlegający nowo utworzonemu Ministerstwu Handlu, a od 1810 r. Ministerstwu Finansów. Nie były to jednak ostatnie zmiany organizacji i nazwy urzędu, ponieważ w 1813 r. Departament Górniczy przemianowano na Departament Górnictwa i Solnictwa (PSZRI, 1830, 31), po czym 50 lat później przywrócono mu poprzednią nazwę, pod którą z ulegającymi zmianom kompetencjami, przetrwał do roku 1918 (Amburger, 1966).

\section{Literatura}

Akty istoričeskie, sobrannye i izdannye Arheografičeskoi komissiej (AI). 1841. Wyd. Tip. II Otdelenija Sobstvennoj Ego Imperatorskogo Veličestva Kancelarii. Sanktpeterburg: t. 2. 
AMBURGER E., 1966. Geschichte der Behördenorganisation Russlands von Peter dem Grossen bis 1917. Wyd. Brill. Leiden.

ANDREEV A.N., 2010. Berg-College and office of the Main Board of Works as the Governament Bodies of Control over the Lutheran Communities in the Ural Mining-Zone in the 18th Century. Journal of Siberian Federal University. Humanities and Social Sciences, 3: 422-428.

ANISIMOV E.B., 1997. Gosudarstvennye preobrazovanija $i$ samoderžavie Petra Velikogo $v$ pervoj četverti XVIII v. Wyd. Dmitrij Bulanin. Sankt-Peterburg.

ANTROPOV D.N., 2013. Obraz gornozavodskogo Urala XVIII v. v illustracijah «Opisanija Ural'skih i Sibirskih zavodov» G.V. de Gennina. Izvestija Ural'skogo federal'nogo universiteta. Serija 2: Gumanitarnye nauki, 4: 86-97.

BABURIN D., 1939. Očerki po istorii Manufaktur kollegii. Moskwa.

BAKŠAEV A.A. 2005. Peredača Goroblagodatskih zavodov v častnye ruki v XVIII v. [W:] Černouhov A.V. (red.) Dokument. Arhiv. Istorija. Sovremennoct'. Sbornik naučnyh trudov. Ekaterinburg, 5. 77-86.

BAL'ZER A., 1844. Izvestie o familii Gg. Šlatšerov, mnogo spospešestvovavših usoveršenstvovaniju gornyh del v Rossii. Gornyj žurnal, ili sobranie svedenij o gornom i soljanom dele, s prisovokupleniem novyh otkrytyh po naukam k semu predmetu otnosjaščimsja, 1. kn. II: 279-296. Sankt-Peterburg.

BERH V.P., 1828. Žizneopisanie Tajnogo Sovetnika Vasilija Nikitiča Tatiščeva, byvšego Sovetnika Berg-Kollegii i Načal'nika vseh Sibirskih Gornyh zavodov. Gornyj žurnal, ili sobranie svedenij o gornom i soljanom dele, s prisovokupleniem novyh otkrytyh po naukam k semu predmetu otnosjaščimsja, 1, 95-134. Sankt-Peterburg.

BJALECKIJ, K.A., 1955. Metallurgičeskaja laboratoria Berg-kollegii. [W:] Šuharin S.V. (red.), Trudy Instituta istorii estestvoznanija i techniki. T. 3: Istorija geologo-geografičeskih nauk, gornoj i metallurgičeskoj nauki i tehniki. Moskwa: 176-183.

BOGDANOVA N.G., 1932. Stihi XVIII veka o rudokopnom dele. [W:] Nikol'skij N.K. (red.), Trudy Komissii po drevnerusskoj literature. Leningrad, 1: 231-246.

BUGROV A., 2012. Ivan Šlatter i ego vklad v razbitie monetnogo dela v Rossii. Bankovskij vestnik. Informacionno-analitičeskij i naučno-praktičeskij žurnal Nacional'nogo banka Respubliki Belarus', 1: 11-17.

Dopolnenija k aktam istoričeskim, sobrannye i izdannye arheografičeskoj komissiej (DAI), 1853. Wyd. Tip. II Otdeleniâ Sobstvennoj Ego Imperatorskogo Veličestva Kancelarii. Sanktpeterburg, 5 .

Dopolnenija k aktam istoričeskim, sobrannye i izdannye arheografičeskoj komissiej (DAI), 1857. Wyd. Tip. II Otdeleniâ Sobstvennoj Ego Imperatorskogo Veličestva Kancelarii. Sanktpeterburg, 6 .

Enciklopedičeskij slovar' Brokgauza i Efrona (ESBE), 1892. Wyd. Semenovskaja Tipolitografija (I.A. Efrona). Sanktpeterburg, 8.

FEJGINA S.A., 1959. Alandskij congress. Vnešniaja politika Rossii v konce Severnoj vojny. Wyd. Akademiâ Nauk SSSR. Moskwa.

GAMEL' I., 1826. Opisanie Tul'skogo oružejnogo zavoda, v istoričeskom i tehničeskom otnošenii. Wyd. Tipografiâ Avgusta Semena. Moskwa.

GEL'BIG G., 1886. Russkie izbranniki i slučajnye ludi. Russkaja starina, 4: 1-180.

GERMAN I.F., 1810. Istoričeskoe načertanie gornogo proizvodstva v Rossijskoj Imperii. Wyd. Gornaja Tipografija. Ekaterinburg 1810: č. 1.

GOLOVŜIKOV K.G., 1881. Rod dvorjan Demidovyh. Wyd. Tip. gub. pravlenija. Jaroslavl'.

HARITONOV, T.V., 2011. Medeplavil'nye zavody Permskogo kraja (XVII-XIX vv.). Perm'.

JANIN E.P., 2004. Iz Prikaza Rudnyh del (Aleksej Timofeevič Lihačev - pervyj rossijskij ministr rudokopnyh del). Wyd. IMGRÈ. Moskwa. 
JUHT A.I., 1985. Gosudarstvennaja dejatel'nost' V.N. Tatiščeva v 20- $h-30-h$ godov XVIII v. Wyd. Nauka. Moskva.

JURKIN I.N., 2007. Andrej Andreevič Vinius, 1641-1716. Wyd. Nauka. Moskwa.

JURKIN I.N., 2013a. Demidov, Tatiščev, Berg- i Manufaktur-kollegija: načalo (po materialam kolležskih prigovorov), [W:] Kornilova G.E. (red.), Desjatye Tatiščevskie čtenija. Vserossijskaja konferencija (Ekaterynburg, 21-22 nojabria 2013 g.). Materialy. Ekaterinburg: 60-66.

JURKIN I.N., 2013b. Šlattery v Berg-kollegii v pervye gody ee suščestvovanija, Petrovskoe vremia v licah: r 400-letiju Doma Romanovyh (1613-2013). [W:] Meščeriakov V.V. \& Saverkina I.V. (red.), Materialy naučnoj konferencji. Sankt-Peterburg: 312-324.

KAFENGAUZ B.B., 1949. Istorija hozâjstva Demidovyh v XVIII-XIX vv. Opyt issledovanija po istorii ural'skoj metalurgii. Wyd. Izdatel'stvo Akademii Nauk SSSR. Moskwa-Leningrad, 1.

KARELIN V.G., 2008. K istorii rukopisi. «Opisanie ural'skih i sibirskih zavodov. 1734». [W:] Kolosova T.A. (red.) Četvertye Čupinskie kraevedčeskie čtenija: materialy konferencii (Ekaterinburg, 14-15 fewralâ 2008 g.). Ekaterinburg, 40-48.

KISELEV M.A., 2009. Organizacija i dejatel'nost' Rudnoj kancelarii v 1715-1718 gg. [W:] Garilov D.V. i in. (red.), Ural industrial'nyj. Bakuninskie čtenija: materialy IX Vseros. nauč. konf., posvjašč. 85-letiju prof. A.V. Bakunina. g. Ekaterinburg, 8-9 okt. 2009 g. Ekaterinburg: t. 2. 51-57.

KISELEV M.A., 2015. Sozdanie Berg-manufaktur-kollegii v 1718 godu. Vestnik Permskogo universiteta, 4: 39-47.

KROKOSZ P., 2010. Rosyjskie sity zbrojne za panowania Piotra I. Wyd. Wydawnictwo Arcana. Kraków.

KROKOSZ P., 2012. Rola rodziny Stroganowów $w$ rozwoju przemystu solnego $w$ Rosji $w$ XVI-XVIII wieku. Studia i materiały do dziejów żup solnych w Polsce. Wieliczka, 28: $189-241$.

KROKOSZ P., 2014. Solnictwo w carskiej Rosji. Organizacja, technika wydobywcza, handel. Studia i materiały do dziejów żup solnych w Polsce. Wieliczka, 29, 165-214.

KURLAEV E.A., 2011. K voprosu o formirovanii sistiemy upravlenija gorno-metallurgičeskoj promyšlennoct'ju Rossii i Urala v XVII - pervoj četverti XVIII v. [W:] Šaškov A.T. (red.), Problemy istorii Rossii. Rossija i Zapad v perehodnuju epohu ot srednevekov'ja $k$ novomu vremeni. Ekaterinburg: vyp. 9. 136-143.

KURLAEV E.A., 2016. Dejatelnost' V.N. Tatiščeva i I.F. Bilera po vozroždeniju vyplavki medi $v$ Kungurskom uezde. Vestnik Permskogo universiteta. Serija Istoria, 1: 96-102.

LORANSKIJ A.M., 1900. Kratkij istoričeskij očerk administrativnyh učreždenij gornogo vedomstva v Rossii 1700-1900 gg. Wyd. Tip. Inženera G.A. Bernštejna. Sankt-Peterburg.

LUBOMIROV P.G., 1937. Očerki po istorii metallugičeskoj i metalloobrabatyvajuščej promyšlennosti v Rossii (XVII, XVIII i nač. XIX vv.). Grografičeskoe razmeščenie metallopromyšlennosti. Wyd. Socekgiz. Leningr. otd-nie. Moskva-Leningrad.

MANIN V.A., 2011. Sistematizacija gornozavodskogo zakonodatel'stva i organizacija upravlenija gornoj otrasl'ju v načale XVIII veka. Pravo. Zakonodatel'stvo. Ličnost'. Naučnyj žurnal, 2, 35-41.

MANIN V.A., 2016. O forme i meste gornozavodskogo zakonodatel'stva $v$ sisteme prava Rossijskogo gosudarstva $v$ XVI-pervoj poloviny XVIII vv. Vestnik Saratovskoj gosudarstvennoj juridičeskoj akademii, 2: 80-85.

MATVEJČUK A., 2014. Po zavetam Petra Velikogo. Stranicy istorii rossijskogo gornotehničeskogo obrazovania. Social'noe partnerstvo, 3, 82-87.

Metallurgičeskie zavody Urala XVII-XX vv. Enciklopedija (MZU), 2001. Wyd. Izdatel'stvo «Akademkniga» Ekaterinburg.

MILLER G.F., 1937. Istorija Sibiri. Priloženija. Wyd. Izdatel'stvo Akademii Nauk SSSR. Moskva-Leningrad. 
MOŠENSKIJ S.Z., 2015. Meždu Londonom i Parižem. Rynok cennych bumag industrial'noj epohi. Wyd. Minstrid Media. Hampton.

NAZAREVSKIJ S.V., 1893. Blagotvoritel'naja dejatel'nost' roda Demidovyh. Wyd. Tip. Ministerstva Vnutrennih Del. Sankt-Peterburg.

Polnoe sobranije zakonov Rosskijskoj Imperii (PSZRI), 1830. Wyd. Tip. II Otdeleniâ Sobstvennoj Ego Imperatorskogo Veličestva Kancelarii. Sanktpeterburg, t. 5.

Polnoe sobranije zakonov Rosskijskoj Imperii (PSZRI), 1830. Wyd. Tip. II Otdelenija Sobstvennoj Ego Imperatorskogo Veličestva Kancelarii. Sanktpeterburg, t. 6.

Polnoe sobranije zakonov Rosskijskoj Imperii (PSZRI), 1830. Wyd. Tip. II Otdelenija Sobstvennoj Ego Imperatorskogo Veličestva Kancelarii. Sanktpeterburg, t. 7.

Polnoe sobranije zakonov Rosskijskoj Imperii (PSZRI), 1830. Wyd. Tip. II Otdelenija Sobstvennoj Ego Imperatorskogo Veličestva Kancelarii. Sanktpeterburg, t. 10.

Polnoe sobranije zakonov Rosskijskoj Imperii (PSZRI), 1830. Wyd. Tip. II Otdelenija Sobstvennoj Ego Imperatorskogo Veličestva Kancelarii. Sanktpeterburg, t. 11.

Polnoe sobranije zakonov Rosskijskoj Imperii (PSZRI), 1830. Wyd. Tip. II Otdelenija Sobstvennoj Ego Imperatorskogo Veličestva Kancelarii. Sanktpeterburg, t. 21.

Polnoe sobranije zakonov Rosskijskoj Imperii (PSZRI), 1830. Wyd. Tip. II Otdeleniâ Sobstvennoj Ego Imperatorskogo Veličestva Kancelarii. Sanktpeterburg, t. 25.

Polnoe sobranije zakonov Rosskijskoj Imperii (PSZRI), 1830. Wyd. Tip. II Otdeleniâ Sobstvennoj Ego Imperatorskogo Veličestva Kancelarii. Sanktpeterburg, t. 31.

PORTAL R., 1950. Ural v XVIII veke. Wyd. Institut d'tudes slaves. Paris.

ROMANOV V.N., 2015. Pervye russkie gornopromyšlenniki. Gornyj informcionno-analitičeskij bjulleten'. (Naučno-tehničeskij žurnal), 3: 327-332.

ru.wikipedia.org/wiki/ История_Екатеринбурга - witryna internetowa Wikipedia, hasło Istorija Jekaterynburga (dostęp: maj 2019).

ru.wikipedia.org/wiki/Брюс,_Яков_Вилимович - witryna internetowa Wikipedia, hasło Jakow Wiliamowicz Brius (dostęp: maj 2019).

ru.wikipedia.org/wiki/Екатеринбург - witryna internetowa Wikipedia, hasło Jekaterynburg (dostęp: maj 2019).

ru.wikipedia.org/wiki/История_Екатеринбурга - witryna internetowa Wikipedia, hasło Historia Jekaterynburga (dostęp: maj 2019).

ru.wikipedia.org/wiki/Тульский_оружейный_завод - witryna internetowa Wikipedia, hasło Tulski Zakład Zbrojeniowy (dostęp: maj 2019).

Russkij biografičeskij slovar' (RBS), 1900. Wyd. Tipografija Glavnogo Upravlenija Udelov. Sanktpetersburg, t. 2.

Russkij biografičeskij slovar' (RBS), 1910. Wyd. Tip. Impieratorskoj Akademii Nauk. Moskva, t. 15 (Pritvic-Rejs).

Russkij biografičeskij slovar' (RBS), 1914. Wyd. Tip. G. Lissnera i D. Sovko. Moskva, t. 4 (Gaag-Gebel').

Russkij biografičeskij slovar' (RBS), 1914. Wyd. Tip. G. Lissnera i D. Sovko. Moskva, t. 10 (Labzina-Lâšenko).

SERCZYK W.A., 1973. Piotr I Wielki. Wyd. Zakład Narodowy imienia Ossolińskich Wydawnictwo. Wrocław-Warszawa-Kraków-Gdańsk.

SPASSKIJ G.I., 1833. Žizneopisanie Akinfija Nikitiča Demidova, osnovatela mnogich gornyh zavodov, coctavlennoe iz aktov, sohranivšihsa u ego naslednikov i iz drugih svedenij. Wyd. Tip. Vdovy Pljušar s synom. Sankt-Peterburg.

VVIEDENSKIJ A.A., 1962. Dom Stroganovyh v XVI-XVII vekah. Wyd. Izdatel'stvo social'no-èkonomičeskoj literatury. Moskwa. 


\title{
MODERNIZATION OF RUSSIAN MINING DURING THE REIGN OF PETER THE GREAT. INTRODUCTION TO THE PROBLEMATICS
}

\author{
College of Mining and Manufactures, \\ mining in Russia in the 16th-18th centuries, \\ tsar Peter the Great, the "Mining privilege" of 1719
}

The article is devoted to the modernization of Russian mining, which took place at the time of the reign of tsar Peter the Great. The article is an introduction to a broader discussion of issues related to the development and functioning of this branch of economy in the Russian Empire. The ordering of issues related to mining of natural resources, especially the metallic ores, was necessary, because it considerably reduced their exports and allowed to make the domestic production much cheaper. The production was most important, because in years 1700-1721 Russia fought with Sweden, and the needs of the tsar's army were enormous. In 1718 a new state of the administration under the official name - College of Mining and Manufactures was created; the state was responsible for protecting all mining affairs of the state. The following year Peter the Great gave the act of law, so-called "Mining privilege", which defined rights related to mining and production metallic ores and minerals. Specialists coming from Western Europe played a big role in the development of the Russian mining, mainly those coming from German countries.

In the article historical sources and elaborations of the Russian's mining in the 16th-18th centuries have been used. The result of the analysis of these materials is a message with information related to the process of the establishing a state office responsible for all matters of the exploration, extraction and processing of all natural resources. 